\title{
Effects of above-limit ground-level ozone concentrations on the health condition of the silver birch (Betula pendula Roth) assimilation apparatus within the period of 2009-2011
}

\author{
E. Bednářová
}

Doc. Ing. Emilie Bednárová, CSc., Faculty of Forestry and Wood Technology, Mendel University in Brno, Zemědèlská3,61300 Brno, Czech Republic,E-mail:bednarov@mendelu.cz

\begin{abstract}
Bednářová, E.: Effects of above - limit ground-level ozone concentrations on the health condition of the silver birch (Betula pendula Roth) assimilation apparatus within the period of 2009-2011. - Beskydy, 5 (1):37-42

Effects of above-limit ground-level ozone concentrations on the health condition of the silver birch (Betula pendula Roth) assimilation apparatus was monitored using the method of study of changes in epicuticular waxes. These waxes are present on the surface of leaves and protect the plant (and, especially, its assimilation apparatus) against negative environmental effects. Studies were performed in a tree stand of the $2^{\text {nd }}$ age category in altitudes ranging from 600 to $1,050 \mathrm{~m}$ in the Ore Mountains (Krušné hory in Czech). It was found out that, as compared with a control stand, the thickness of the wax epicuticular layer decreased with the increasing altitude while concentrations of the ground-level ozone increased. A visible damage of the assimilation apparatus was observed in localities with the highest concentrations of ground-level ozone. Here, not only an overall decrease in the amount of epicuticular waxes was observed but also a degradation of their structure. A statistical analysis of results proved that the loss of epicuticular waxes was significantly dependent on above-limit concentrations of ground-level ozone.
\end{abstract}

Keywords: ground-level ozone, altitude, air pollution, epicuticular waxes, damage, silver birch

\section{Introduction}

In the recent decade, the spectrum of imissions changed (and improved) within the whole territory of Czech Republic. From the viewpoint of forest ecosystems and natural vegetation protection, limit $\mathrm{SO}_{2}$ concentrations were not exceeded in any locality. However, new factors influencing the health condition of forest ecosystems came to the foreground and became more and more prominent. In the Ore Mountains (in Czech Krušné hory), besides a worsened condition of soil caused by acid deposits, the health condition of forest stands was negatively influenced above all by above-limit concentrations of ground-level ozone in these localities.

Ozone is one of the most frequently discussed gases that influence vitality of forest woody species. In regions with higher anthropogenic load, ozone and acid deposits are the primary causes of stand damages (Hůnová, Novák 2001, Šrámek et al. 2007, Bednářová, Truparová 2010, Bednářová, Kučera 2011). For the time being, concentrations of ground-level ozone are considered to be the most significant noxious gas agent influencing the health condition of European forests (Ashmore 2003). Ozone noxiousness is dependent on detoxification capabilities of plants and its intensity differs as far as individual woody species are concerned (Ditmar et al. 2004). Experimentally, a relatively high sensibility of silver birch was demonstrated by several authors (e.g. Skelly et al. 1998, Karnosky et al. 2002, 2003 and others).

Ozone penetrates into the plant organism through stomata and is decomposed very 
quickly already in inter-cellular spaces due to the contact with wet cell walls (Gloser, Prášil 1998). This means that the water intake is directly influenced by atmospheric concentrations of ozone, properties of the laminar layer of assimilation organs, and stomatal conductance. With the increasing damage of plants, a plasmolysis of individual cells takes place together with an overall distortion of cellular structures (Günthardr-Georg et al. 2000). Epidermal cells collapse later than those of mesophyll. In the course of upper mesophyll cells dieback, the damage is manifested with visible necrotic spots on the leaf surface (Ditmar et al. 2004). Together with the cuticle and epicuticular waxes, the epidermis represents a plant-environment interface. Epicuticular waxes protect the surface of leaves and needles against negative environmental effects. The damage of cuticle may be caused by the action of above-limit concentrations of ground-level ozone (Lendzian, Kerstiens 1988). The monitoring and evaluation of changes in amounts and structure of epicuticular waxes on the surface of leaves and needles represent one of frequently used tools and markers of the degree of the assimilation apparatus damage by noxious substances.

\section{Material and methods}

In the Ore Mountains range, the health condition of the assimilation apparatus of silver birch (Betula pendula Roth) was evaluated within the altitude gradient from 600 to $1,050 \mathrm{~m}$ using the method of monitoring changes taking place in amounts and structure of epicuticular waxes present on the surface of its leaves. Since 2002, the concentration of ground-level ozone was measured directly in birch stands using passive dosimeters (manufacturer Gradko International Ltd., United Kingdom). These dosimeters were exchanged in four-week intervals within the growing period, i.e. from the beginning of April to the end of October. Ground-level ozone concentrations were evaluated directly by the
Gradko International Ltd. All measurements were performed in silver birch stands of the $2^{\text {nd }}$ age category and attention was paid to changing air pollution spectra and environmental parameters. Samples of plant material were taken from three trees growing in each of long-term monitored localities always during the first week of September. The amount of epicuticular waxes on the leaf surface was estimated in laboratory using the method published by Günthardt et al. (1994). Structural changes of epicuticular waxes were evaluated using the scanning electron microscope (SEM). Environmental parameters were assessed on the basis of continual measurements of air temperature using sensors mounted in the lower part of tree crowns (i.e. in the same height as passive dosimeters). Intensity of global radiation and precipitations were continuously monitored on the open area (Sv. Anna). To register these parameters, independent logging sensors Minikin T and Minikin RT (manufactured by EMS Brno) were used. Characteristics of the study area with stands of silver birch in the Ore Mountains are presented in Tab. 1.

\section{Results and discussion}

This study is a continuation of a thirteen-year study dealing with the damages to the assimilation apparatus of silver birch forest stands due to anthropogenic effects (Bednářová, Kučera 2011). Within the period of 2009-2011, the highest amounts of epicuticular waxes on the surface of silver birch leaves were repeatedly recorded in the lowest locality Orasín $(600 \mathrm{~m}$ above sea level). Within the whole study period, the amount of epicuticular waxes did not drop below $59 \mathrm{mg} . \mathrm{g}^{-1} \mathrm{DM}$ (dry matter content). In this locality no concentrations of ground-level ozone were recorded that would exceed the health limit determined for forest woody species (i.e. $80 \mu \mathrm{g} . \mathrm{m}^{-3}$ ). In the course of the whole growing season (from May to August), average ground-level ozone concentrations were not higher than $70 \mu \mathrm{g} . \mathrm{m}^{-3}$ in all years of this study.

Tab. 1: List of experimental plots.

\begin{tabular}{lcccccc}
\hline \multicolumn{1}{c}{ Plot } & $\begin{array}{c}\text { Altitude } \\
{[\mathbf{m}]}\end{array}$ & Latitude & Longtitude & $\begin{array}{c}\text { Forest } \\
\text { type }\end{array}$ & $\begin{array}{c}\text { Temperature } \\
{\left[{ }^{\circ} \mathbf{C}\right]}\end{array}$ & $\begin{array}{c}\text { Precipitation } \\
{[\mathbf{m m}]}\end{array}$ \\
\hline Kalek & 730 & $50^{\circ} 35,35$ & $13^{\circ} 19,98$ & $7 \mathrm{~K}$ & 5.58 & 912 \\
Srní & 825 & $50^{\circ} 22,71$ & $13^{\circ} 02,25$ & $6 \mathrm{~K} 1$ & 5.83 & 862 \\
Sv. Anna & 875 & $50^{\circ} 33,14$ & $13^{\circ} 18,87$ & $7 \mathrm{~K}$ & 5.33 & 912 \\
Janov & 900 & $50^{\circ} 33,15$ & $13^{\circ} 22,67$ & $7 \mathrm{~K}$ & 5.45 & 912 \\
Meluzina & 1050 & $50^{\circ} 23,48$ & $13^{\circ} 00,75$ & $7 \mathrm{~K} 2$ & 4.09 & 862 \\
\hline
\end{tabular}


Tab.2: The quantity of epicuticular waxes in birch (Betula pendula Roth) [mg.g-1 DM].

\begin{tabular}{|c|c|c|c|c|}
\hline \multirow{2}{*}{ Localities } & \multirow{2}{*}{$\begin{array}{c}\text { Altitude } \\
\text { [mm] }\end{array}$} & \multicolumn{3}{|c|}{ Year } \\
\hline & & 2009 & 2010 & 2011 \\
\hline Orasín & 600 & 59 & 59 & 59 \\
\hline Kalek & 730 & 55 & 54 & 56 \\
\hline Srní & 825 & 51 & 50 & 51 \\
\hline Sv. Anna & 880 & 46 & 44 & 47 \\
\hline Janov & 900 & 41 & 39 & 42 \\
\hline Meluzína & 1050 & 37 & 35 & 37 \\
\hline
\end{tabular}

Amounts of epicuticular waxes (inmg.g-1 of leaf DM) recorded in experimental silver birch stands in the Ore Mountains are presented in Tab. 2. In individual years, amounts of epicuticular waxes differed only slightly and the highest values were always recorded in the lowest experimental localities. With the increasing altitude, amounts of epicuticular waxes on leaves of silver birch decreased. In 2009, the measured amounts of epicuticular waxes ranged from 37 to $55 \mathrm{mg} \cdot \mathrm{g}^{-1} \mathrm{DM}$ in localities situated in altitudes between 730 and 1,050 m. In 2010, recorded values were slightly lower ( 35 to $54 \mathrm{mg} \cdot \mathrm{g}^{-1} \mathrm{DM}$ ) and in 2011 the decrease in the amount of epicuticular waxes was lower as compared with the preceding year. Total amounts of epicuticular waxes ranged from 37 to $56 \mathrm{mg}$. ${ }^{-1} \mathrm{DM}$. The statistical analysis revealed a high linear correlation between amounts of epicuticular waxes and stand altitude. In 2009 year, the calculated correlation coefficient was $\mathrm{R}^{2}=0.91$ ( $\mathrm{y}=-0.059 \mathrm{x}$ + 98.11), while in 2010 and 2011, its values were $\mathrm{R}^{2}=0.90(\mathrm{y}=-0.063 \mathrm{x}+99.70)$ and $\mathrm{R}^{2}=0.94(\mathrm{y}=$ $-0.062 x+100.65)$ respectively.

The highest four-week averages of groundlevel ozone concentrations are presented in Tab. 3. In 2009, the maximum average monthly value of ground-level ozone concentrations (122 $\mu \mathrm{g} . \mathrm{m}^{-3}$ ) was recorded in birch stands situated in the altitude of $900 \mathrm{~m}$. In 2010, the highest concentration of ground-level ozone was as much as $49 \mu \mathrm{g} \cdot \mathrm{m}^{-3}$ (900 $\mathrm{m}$ above sea level). In 2011 ozone concentrations decreased in all localities (ground-level ozone was as much as $139 \mu \mathrm{g} \cdot \mathrm{m}^{-3}$ at an altitude $1050 \mathrm{~m}$ ).

Average concentrations of ground-level ozone, as measured within the whole growing season (May - August) are presented in Tab. 4. In 2009, the limit concentrations of ground-level ozone were exceeded in all localities situated in

Tab. 3: Air pollution: highest montly averages of ground ozone concentrations.

\begin{tabular}{lcccc}
\hline \multirow{2}{*}{ Localities } & \multirow{2}{*}{$\begin{array}{c}\text { Altitude } \\
{[\mathbf{m}]}\end{array}$} & $\mathbf{2 0 0 9}$ & $\mathbf{2 0 1 0}$ & $\mathbf{2 0 1 1}$ \\
\cline { 3 - 5 } Kalek & 730 & 83 & 98 & 81 \\
Srní & 825 & 106 & 125 & 110 \\
Sv. Anna & 880 & 121 & 140 & 114 \\
Janov & 900 & 122 & 149 & 105 \\
Meluzína & 1050 & 121 & 139 & 139 \\
\hline
\end{tabular}

Tab. 4: Average ground ozone concentration during the growing season (V-VIII month).

\begin{tabular}{lcccc}
\hline \multirow{2}{*}{ Localities } & Altitude & \multicolumn{3}{c}{ Year } \\
\cline { 3 - 5 } & {$[\mathbf{m}]$} & $\mathbf{2 0 0 9}$ & $\mathbf{2 0 1 0}$ & $\mathbf{2 0 1 1}$ \\
\hline Kalek & 730 & 74 & 86 & 71 \\
Srní & 825 & 93 & 107 & 92 \\
Sv. Anna & 880 & 108 & 116 & 99 \\
Janov & 900 & 105 & 121 & 100 \\
Meluzina & 1050 & 109 & 114 & 110 \\
\hline
\end{tabular}


altitudes higher than $800 \mathrm{~m}$. As far as the whole growing season was concerned, the maximum value was measured in the altitude of $1,050 \mathrm{~m}$. In 2010, prolonged above-limit concentrations of ground-level ozone occurred in all localities above the altitude of $730 \mathrm{~m}$. The maximum ozone concentration was recorded in the altitude of $900 \mathrm{~m}\left(121 \mu \mathrm{g} . \mathrm{m}^{-3}\right)$. In the growing season of 2011, when ground-level ozone concentrations generally decreased, above-limit values were recorded in silver birch stand situated in altitudes above $800 \mathrm{~m}$. In this year, the maximum value of $110 \mu \mathrm{g} . \mathrm{m}^{-3}$ was measured in the altitude of $1,050 \mathrm{~m}$.

A statistical analysis revealed the existence of a linear correlation between the amount of epicuticular waxes and concentrations of ground-level ozone. In 2009, this correlation was $R^{2}=0.7617(y=-1.7689 x+179.17)$ while in years 2010 and 2011 the corresponding values were $R^{2}=0.6634(y=-1.4370 x+172.60)$ and $R^{2}=$ $0.8698(\mathrm{y}=-1,8273 \mathrm{x}+179.55)$ respectively.

In localities with above-limit concentrations of ground-level ozone, chlorotic spots (but without leaf nervature damages) were observed on silver birch leaves and these were visible also on their lower side (Fig. 1). A detailed SEM study of tissue samples revealed a considerable structural degradation of epicuticular waxes (Fig. 2).

Visible symptoms of a negative ozone action occurred already several weeks after the bud unfolding and leaf development, above all in
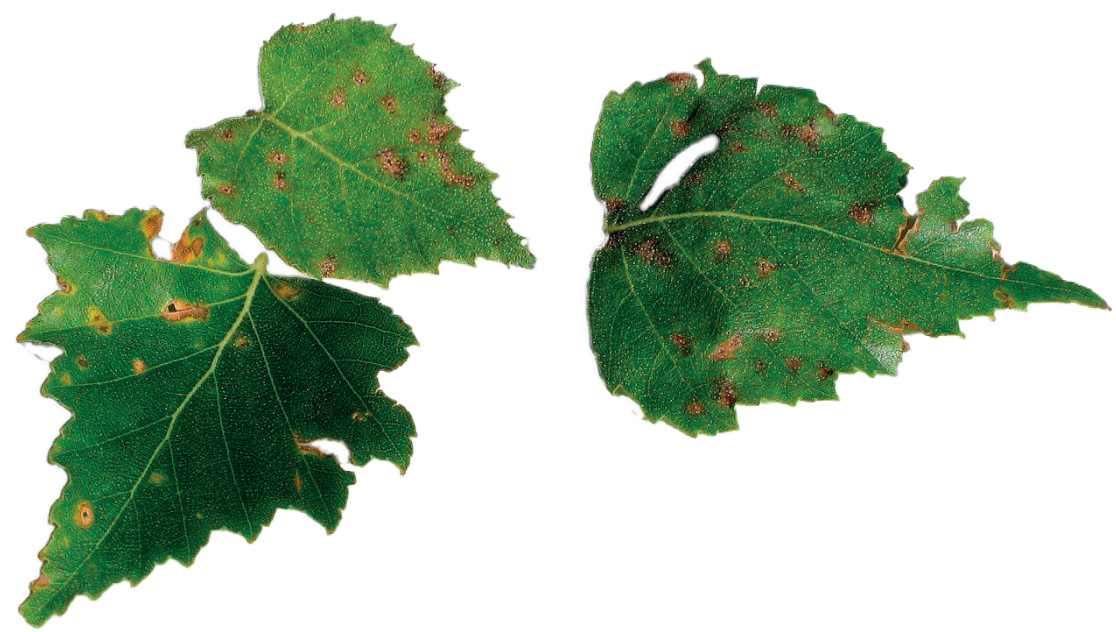

Fig. 1: Ozon damage on birch leaves.

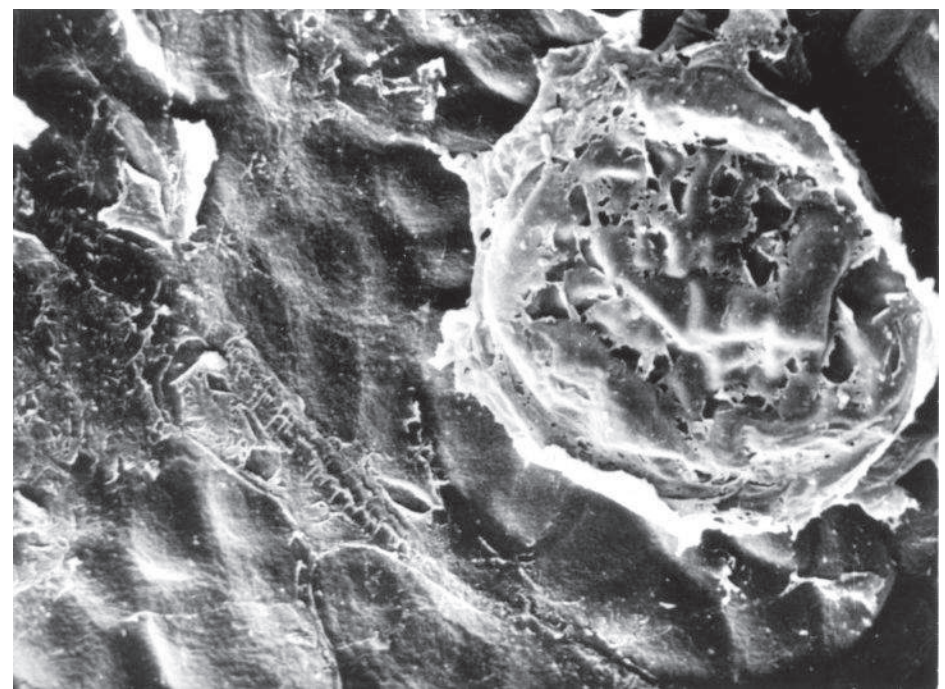

Fig. 2: Damaged epicuticular waxes structure on birch leaves. 
stands growing on south to southwest slopes. This observation corresponded with data published by Günthardt-Georg, Vollenweider (2003) as well as with a description of symptoms of a visible leaf damage caused by the action of ground-level ozone (Novotný et al. 2009).

Epicuticular waxes create a barrier between the leaf surface and the environment. An insufficient and degraded wax layer is not able to protect the assimilation apparatus against negative effects of exogenous factors, UV radiation, fungal diseases, viruses and insects. This fact was mentioned also by Karnosky et al. (2002), Mengden (1996) and Percy et al. (2002). The damage of assimilation apparatus due to anthropogenic effects may be reflected also in the overall health condition of woody species under study. A good knowledge of the development and function of epicuticular waxes on leaves of silver birch may contribute to the explanation of causes of the damage of those woody species that have been continuously influenced by human activities and that are still under the anthropogenic load.

\section{Conclusions}

A study on effects of ground-level ozone concentrations on health condition of silver birch assimilation apparatus by means of a method of assessment of changes taking place in amounts of epicuticular waxes demonstrated a significant effect of above-ground ozone on their total amount and structure. Epicuticular waxes, which play a protective role as far he assimilation apparatus of plants is concerned, were very damaged by above-limit concentrations of ground-level ozone. This dependence was statistically demonstrated by a high coefficient of determination. Amounts of epicuticular

\section{References}

Ashmore, M. 2003: Air pollution impacts on vegetation in Europe. In. Emberson, L., Ashmore, M., Urray, F. (eds.) Air pollution impacts on crops and forests. A global assessment, Imperial, College press, London, 59-88.

BednáŘová, E., Truparová, S. 2010: The condition of Norway spruce epicuticular waxes at higher altitudes in 2005-2009. Beskydy, 3 (2): 115-120.

BednÁŘovÁ, E., KuČERA, J. 2011: Monitoring the damage to epicuticular waxes at silver birch waxes found on the surface of silver birch leaves were changing due to concentrations of aboveground ozone recorded in localities under study in individual years and generally decreased with the increasing altitude. In the altitude of $600 \mathrm{~m}$, samples of epicuticular waxes collected in the control stand, remained to be the same within the whole study period. In this locality, the above-limit concentrations of ground-level ozone were measured during the whole study period while in all other silver birch stands that were growing in altitudes above $800 \mathrm{~m}$, harmful concentrations of above-ground ozone were recorded in all stands growing in altitudes above $900 \mathrm{~m}$ where the typical ozone-caused damage of assimilation apparatus was visible just at the first sight. A detailed SEM study of tissue samples revealed a considerable structural degradation of epicuticular waxes. Besides above-limit concentrations of ground-level ozone, this degradation of epicuticular waxes might be caused also by unfavourable climatic conditions existing in these high altitudes. The leaf cuticle and, above all, its external wax layer create and important barrier that protects plants against noxious substances. In case that it is damaged or reduced, negative factors of the ambient environment may influence also some other physiological processes. The obtained information about the damage of the assimilation apparatus of forest woody species, which plays an important role in production of biomass and can significantly contribute to the explanation of damages of forest woody species caused in mountainous regions by anthropogenic factors.

\section{Acknowledgement}

This paper was writen in the framework of the projects VZMSM 621564890.
(Betula pendula Roth) in the changing air pollution spectrum of the Ore Mountains. Acta Universitatis Agriculturae et Silviculturae Mendelianae Brunensis, LIX, No 5: 9-16.

Ditmar, C., Elling, W., Günthardt - Georg, M., Mayer, F. J., Gilge, S., Winkler, P., Fricke, E. 2004: Ozonbelastung and Schadsymptome im Extremmer 2003. AFZ - Der Wald, 683$685 \mathrm{~S}$.

Gloser, J., Prášil, I. 1998: Fyziologie stresu [Physiology of stress]. In: ProchÁzKa, S., Macháčková, I. Krekule, J., Šebánek, J. Fyziologie rostlin. Praha, Academia, s. 412-431. 
Günthardt, M., Keller, T., Matyssek, R., ScHEIDGER, C. 1994: Environmental effects on Norway spruce needle wax. European Journal of Plant Pathology, 224: 92-111.

Günzhardt-Georg, M., S. Mcquateie, C. J., Maurer, S., Frey, B. 2000: Visible and microscopic injury in leaves of five deciduous tree species related to current critical ozone levels. Environmental Pollution, 109: 89-500.

Günthardt - Georg, M., S., Vollenweider, P. 2003: Microscopy for differential diagnostic of foliar ozone symptoms. In: 4th International Training Course Ozone Visible Injury. Switzerland, Birmensdorf 25-27 th August. Oral power-point presentation (http://www. wsl.ch/ozone/ICP-Forests_results.html).

Hunová, I., NovÁK, V. 2001: Expoziční index AOT 40 jako nástroj pro odhad účinku přízemního ozonu na ekosystémy. [Exposure index AOT 40 a tool for assessment of ground /level ozone impact on ecosystems]. Meteorologickézprávy, 54(3): 64-72.

Karnosky, D. F., Mañkovská, B., Percy, K., Dickson, R. E., Podila, G. K., Sober, J. 1999: Effect of trophospheric $\mathrm{O}_{3}$ on trembling aspen and interaction with $\mathrm{CO}_{2}$ : Results from an $\mathrm{O}_{3}$ gradient and FACE experiment. Water Air Soil Pollution, 116: 311-322.

Karnosky, D. F., Zak, D. R., Pregitzer, K. S., Awмack, C. S. 2003: Tropospheric $\mathrm{O}_{3}$ moderatesresponse of temperate hardwood forests to elevated $\mathrm{CO}_{2}$ : A synthesis of molecular to ecosystems results from the Aspen. Face project. Functional Ecology, 17: 289-304.

Lendzian, K., Kerstiens, G. 1988: Interaction between plant cuticles and graseous air pollutants. Environmental aspects of applied biology. University of York, UK, 19-21, Sept. 1988. Aspects of Applied Biology, 17 (2): 97-104.

Mengden, K. 1966: Fungal attachment and penetration. In: Kerstiens, G. (ed.) Plant Cuticles. Bios Scientific Publisher, 175-188.

NovotnÝ, R., BuriâneK, V., ŠrÁmeK, V. 2009: Metodika hodnocení viditelného poškození vegetace vyvolaného účinky přízemního ozonu [Methodolgy for assesment of vegetation damage in forest ecosystems by high concentrations of trophospheric ozone]. VÚLHM, Jíloviště-Strnady, Recenzovaná metodika, Lesnický privvodce, 6: 1-48 s.

Percy, K. E., Awmack, C. S., Lindroth, R. L., KuBISKE, M. E. 2002: Altered performance of forests pests under $\mathrm{CO}_{2}$ and $\mathrm{O}_{3}$ enriched atmosphere. Nature, 420: 403-407.

SKelly, J. M., InNes, J., SNYder, K. 1998: Investigation of ozone inducted injury in forests of southerm Switzerland: Field survays and open top chamber experiments. Chemosphere, 36: 995-1000.

ŠrámeK, V., NovotnÝ, R., BednáŘová, E., Uhlî́rovÁ, H. 2007: Monitoring of ozone risk for forests in the Czech Republic: Preliminary results. The Scientific World Journal, 7 (1): 78-83. 